\title{
Mackerel Trypsin Purified from Defatted Viscera by Supercritical Carbon Dioxide
}

\section{Byung-Soo Chun, ${ }^{1}$ Hideki Kishimura, ${ }^{2}$ Sitthipong Nalinanon, ${ }^{3}$ Sappasith Klomklao, ${ }^{4}$ and Soottawat Benjakul ${ }^{5}$}

${ }^{1}$ Department of Food Science and Technology, Pukyong National University, Busan 608-737, Republic of Korea
${ }^{2}$ Research Faculty of Fisheries Sciences, Hokkaido University, Hakodate, Hokkaido 041-8611, Japan
${ }^{3}$ Faculty of Agro-Industry, King Mongkut's Institute of Technology Ladkrabang, Choakhunthaharn Building,
Choakhunthaharn Rd., Ladkrabang, Bangkok 10520, Thailand
${ }^{4}$ Department of Food Technology, Faculty of Agro-Industry, Prince of Songkla University, Hat Yai, Songkhla 90112, Thailand
${ }^{5}$ Department of Food Science and Technology, Faculty of Technology and Community Development, Thaksin University,
Phattalung Campus, Phattalung 93110, Thailand

Correspondence should be addressed to Hideki Kishimura, kishi@fish.hokudai.ac.jp

Received 22 February 2011; Accepted 10 May 2011

Academic Editor: Moncef Nasri

Copyright ( $) 2011$ Byung-Soo Chun et al. This is an open access article distributed under the Creative Commons Attribution License, which permits unrestricted use, distribution, and reproduction in any medium, provided the original work is properly cited.

\begin{abstract}
Viscera of mackerel (Scomber sp.) were defatted by supercritical carbon dioxide $\left(\mathrm{SCO}_{2}\right)$ treatment. Trypsin (SC-T) was then extracted from the defatted powder and purified by a series of chromatographies including Sephacryl S-200 and Sephadex G-50. The purified SC-T was nearly homogeneous on SDS-PAGE, and its molecular weight was estimated as approximately 24,000 Da. $N$-terminal twenty amino acids sequence of SC-T was IVGGYECTAHSQPHQVSLNS. The specific trypsin inhibitors, soybean trypsin inhibitor and TLCK, strongly inhibited the activities of SC-T. The $\mathrm{pH}$ and temperature optimums of SC-T were at around $\mathrm{pH} 8.0$ and $60^{\circ} \mathrm{C}$, respectively, using $N^{\alpha}$-p-tosyl-L-arginine methyl ester as a substrate. The SC-T was unstable below pH 5.0 and above $40^{\circ} \mathrm{C}$, and it was stabilized by calcium ion. These enzymatic characteristics of SC-T were the same as those of other fish trypsins, especially spotted mackerel ( $S$. borealis) trypsin, purified from viscera defatted by acetone. Therefore, we concluded that the $\mathrm{SCO}_{2}$ defatting process is useful as a substitute for organic solvent defatting process.
\end{abstract}

\section{Introduction}

Fish viscera are one of the sources of digestive enzymes that may have some unique properties of fascinate with both basic research and industrial applications. Their survival in waters required adaptation of their enzyme activity to low temperatures of their habitats. That is to say, fish proteinases have higher catalytic efficiency at low temperatures than those from warm-blooded animals $[1,2]$. In addition, the strong positive correlation between the habitat temperature of marine fish and the thermostability of its trypsin has been demonstrated [3-11]. High activity at low temperatures and instability against heat, low $\mathrm{pH}$, and autolysis of fish proteinases are interesting for some industrial applications [12]. Cod trypsin is already practically used in food production and cosmetics [13, 14]. Furthermore, Pacific cod and Atlantic cod trypsins were utilized as catalyst of enzymatic peptide synthesis $[9,15]$.

On the other hand, lipids in the tissue prevent from extracting, preparing, and purifying enzymes [16]. Conventional methods for the removal of lipids from materials involve cooking, pressing, and liquid extraction. On liquid extraction for enzyme preparation, it is usually used with organic solvents, such as hexane, ethanol, and acetone, and so forth $[16,17]$. However, The removal of lipids with organic solvents causes protein denaturation and/or loss of functional properties [18]. Organic solvents are also highly flammable and are toxic for human health. Consideration of such factors has led investigators to apply supercritical fluid extraction techniques to the lipid separation [19]. 
Carbon dioxide $\left(\mathrm{CO}_{2}\right)$ is a popular supercritical extractant particularly in food processing, flavor and aroma isolation, and pharmaceuticals manufacture, because $\mathrm{CO}_{2}$ is nontoxic and does not leave a residue. Supercritical $\mathrm{CO}_{2}\left(\mathrm{SCO}_{2}\right)$ has been used for extraction of oils from some marine organisms [20-22]. But, the aims of these studies were mainly the gain of oils rich in polyunsaturated fatty acids, especially EPA and DHA. So, the application of $\mathrm{SCO}_{2}$ for isolation of enzymes and production of quality protein meal from different sources should be examined.

Recently, we prepared a defatted powder of squid viscera treating with $\mathrm{SCO}_{2}$ and detected protease, lipase, and amylase activities in crude extract from the powder [18]. Next, we purified a phospholipase $A_{2}$ from the starfish pyloric ceca defatted by $\mathrm{SCO}_{2}$ extraction process [23]. In this study, with the aim of utilization of fish trypsin for food industry, we purified a trypsin (SC-T) from the mackerel viscera powder treated by $\mathrm{SCO}_{2}$ defatting process and compared its enzymatic properties with those of other fish trypsins purified from the viscera defatted by acetone.

\section{Materials and Methods}

2.1. Materials. Mackerel (Scomber sp.) were caught off Busan, Republic of Korea. The mackerel viscera were collected from F \& F Co., Busan, Republic of Korea, and the visceral waste was brought to the laboratory in iced condition. The $\mathrm{CO}_{2}$ (99.99\% pure) was supplied by KOSEM, Korea. Sephacryl S-200 and Sephadex G-50 were purchased from GE Healthcare UK Ltd. (Amersham, UK). $N^{\alpha}$-p-Tosyl-Larginine methyl ester hydrochloride (TAME) and Ethylenediaminetetraacetic acid (EDTA) were obtained from Wako Pure Chemicals (Osaka, Japan). 1-(L-trans-epoxysuccinylleucylamino)-4-guanidinobutane (E-64), soybean trypsin inhibitor, $N$-p-tosyl-L-lysine chloromethyl ketone (TLCK), and pepstatin A were purchased from Sigma Chemical Co. (St. Louis, Mo, USA).

2.2. Condition of Supercritical Fluid Defatting. The defatted powder of mackerel viscera was prepared as described by Chun et al. [23] using semibatch type of supercritical fluid extraction unit. The lipid extraction by $\mathrm{SCO}_{2}$ was performed at temperature of $45^{\circ} \mathrm{C}$ and pressure of $25 \mathrm{MPa}$. The total extraction time was $2.5 \mathrm{~h}$. The $\mathrm{SCO}_{2}$ defatted powder was stored at $-60^{\circ} \mathrm{C}$ until further analysis.

2.3. Purification of Mackerel Trypsin (SC-T) from $\mathrm{SCO}_{2}$ Defatted Powder. Trypsin was extracted by stirring from $10.0 \mathrm{~g}$ of defatted powder in 50 volumes of $10 \mathrm{mM}$ Tris$\mathrm{HCl}$ buffer ( $\mathrm{pH} 8.0$ ) containing $1 \mathrm{mM} \mathrm{CaCl}_{2}$ at $5^{\circ} \mathrm{C}$ for $3 \mathrm{~h}$. The extract was centrifuged (H-200, Kokusan, Tokyo, Japan) at $10,000 \mathrm{xg}$ for $10 \mathrm{~min}$, and then the supernatant was concentrated by lyophilization and used as crude trypsin $(50 \mathrm{~mL})$. Ten milliliters of crude trypsin was applied for four times to a column of Sephacryl S-200 $(3.9 \times 64 \mathrm{~cm})$ preequilibrated with $10 \mathrm{mM}$ Tris- $\mathrm{HCl}$ buffer $(\mathrm{pH}$ 8.0) containing $1 \mathrm{mM} \mathrm{CaCl}_{2}$, and proteins were eluted $(0.8 \mathrm{~mL} / \mathrm{min})$ with the same buffer. Each main trypsin fractions were gathered and concentrated by lyophilization. Then the concentrated fraction $(10 \mathrm{~mL})$ was applied to a Sephadex G-50 column $(3.9 \times 64 \mathrm{~cm})$ pre-equilibrated with the above buffer, and proteins were eluted $(0.7 \mathrm{~mL} / \mathrm{min})$ with the same buffer. A single trypsin fraction was pooled and used as purified trypsin (SC-T).

2.4. Assay for Trypsin Activity. Trypsin activity was measured by the method of Hummel [24] using TAME as a substrate. One unit of enzyme activity was defined as the amount of the enzyme hydrolyzing one micromole of TAME in a minute. The effect of inhibitors on trypsin was determined by incubating trypsin with an equal volume of proteinase inhibitor solution to obtain the final concentration designated $(0.1 \mathrm{mM} \mathrm{E}-64,1 \mathrm{mg} / \mathrm{mL}$ soybean trypsin inhibitor, $5 \mathrm{mM}$ TLCK, $1 \mathrm{mM}$ pepstatin A and $2 \mathrm{mM}$ EDTA) [25]. After incubation of the mixture at $25^{\circ} \mathrm{C}$ for $15 \mathrm{~min}$, the remaining activity was measured, and percent inhibition was then calculated. The $\mathrm{pH}$ dependencies of trypsin were determined in $50 \mathrm{mM}$ buffer solutions [acetic acid-sodium acetate $(\mathrm{pH}$ 4.0-7.0), Tris- $\mathrm{HCl}(\mathrm{pH} 7.0-9.0$ ), and glycine- $\mathrm{NaOH}(\mathrm{pH}$ $9.0-11.0$ ) ] at $30^{\circ} \mathrm{C}$. The temperature dependencies of trypsin were determined at $\mathrm{pH} 8.0$ and at various temperatures. The temperature and $\mathrm{pH}$ stabilities of trypsin were found by incubating enzyme at $\mathrm{pH} 8.0$ for $15 \mathrm{~min}$ at a range of 20 $80^{\circ} \mathrm{C}$ and by incubating the enzyme at $30^{\circ} \mathrm{C}$ for $30 \mathrm{~min}$ at a range of $\mathrm{pH} 4.0-11.0$, respectively. The effect of $\mathrm{CaCl}_{2}$ on trypsin activity was found by incubating the enzyme at $30^{\circ} \mathrm{C}$ and at $\mathrm{pH} 8.0$ in the presence of $10 \mathrm{mM}$ EDTA or $10 \mathrm{mM}$ $\mathrm{CaCl}_{2}$.

2.5. Sodium Dodecyl Sulfate-Polyacrylamide Gel Electrophoresis (SDS-PAGE). SDS-PAGE was carried out using a $0.1 \%$ SDS- $13.75 \%$ polyacrylamide slab gel by the method of Laemmli [26]. The gel was stained with $0.1 \%$ Coomassie Brilliant Blue R-250 in 50\% methanol-7\% acetic acid, and the background of the gel was destained with $7 \%$ acetic acid.

2.6. Analysis of Amino Acid Sequence. To analyze the Nterminal amino acid sequence of SC-T, the enzyme was electroblotted to a polyvinylidene difluoride (PVDF) membrane after SDS-PAGE. The amino acid sequence of the enzyme was analyzed by using a protein sequencer, Procise 492 (Perkin Elmer, Foster City, Calif, USA).

2.7. Protein Determination. The protein concentration was determined by the method of Lowry et al. [27] using bovine serum albumin as a standard.

\section{Results and Discussion}

3.1. Effect of $\mathrm{SCO}_{2}$ Defatting Process for Trypsin Activity. The viscera of mackerel (Scomber sp.) were treated by $\mathrm{SCO}_{2}$ to separate lipids on the condition of $40^{\circ} \mathrm{C}, 25 \mathrm{MPa}$, and $2.5 \mathrm{~h}$. Since $\mathrm{SCO}_{2}$ extracted almost all oil from the squid viscera in the previous study, we adopted the condition to remove lipids from the mackerel viscera [18]. Trypsin was then extracted from $10.0 \mathrm{~g}$ of defatted powder by $\mathrm{SCO}_{2}$, and the 
TABle 1: Purification of trypsin (SC-1) from mackerel viscera defamed by $\mathrm{SCO}_{2}$.

\begin{tabular}{lccccc}
\hline $\begin{array}{l}\text { Purification } \\
\text { stages }\end{array}$ & $\begin{array}{c}\text { Protein } \\
(\mathrm{mg})\end{array}$ & $\begin{array}{c}\text { Total } \\
\text { activity } \\
(\mathrm{U})\end{array}$ & $\begin{array}{c}\text { Specific } \\
\text { activity } \\
(\mathrm{U} / \mathrm{mg})\end{array}$ & $\begin{array}{c}\text { Purification } \\
(\text { fold })\end{array}$ & $\begin{array}{c}\text { Yield } \\
(\%)\end{array}$ \\
\hline Crude enzyme & 1,390 & 1,049 & 0.8 & 1 & 100 \\
Sephacryl S-200 & 502 & 946 & 2 & 3 & 90 \\
Sephadex G-50 & 15 & 547 & 36 & 48 & 50 \\
\hline
\end{tabular}

TABLE 2: Effects of various inhibitors on the activity of SC-T ${ }^{\mathrm{a}}$.

\begin{tabular}{lcc}
\hline Inhibitors & Concentration & \% Inhibition \\
\hline Control & - & 0 \\
Soybean trypsin inhibitor & $1 \mathrm{mg} / \mathrm{mL}$ & 100 \\
TLCK & $5 \mathrm{mM}$ & 92 \\
E-64 & $0.01 \mathrm{mM}$ & 0 \\
Pepstatin A & $0.01 \mathrm{mM}$ & 0 \\
EDTA & $2 \mathrm{mM}$ & 0 \\
\hline
\end{tabular}

aThe enzyme solution was incubated with the same volume of inhibitor at $25^{\circ} \mathrm{C}$ for $15 \mathrm{~min}$, and residual activity was analysed using TAME as a substrate for $5 \mathrm{~min}$ at $\mathrm{pH} 8.0$ and $30^{\circ} \mathrm{C}$.

crude enzyme was prepared. As shown in Table 1, the crude enzyme contained $1,390 \mathrm{mg}$ of total protein and $1,049 \mathrm{U}$ of total trypsin activity. Previously, we extracted trypsin from the pyloric ceca powder $(13.9 \mathrm{~g})$ of spotted mackerel defatted by acetone, and 3,633 $\mathrm{mg}$ of total protein and 3,270 $\mathrm{U}$ of total trypsin activity were detected in the crude enzyme solution [5]. Although these data were not compared directly, the yields of protein and trypsin activity per weight of acetone powder were approximately two times higher than those of $\mathrm{SCO}_{2}$ powder. However, the specific activity $(0.8 \mathrm{U} / \mathrm{mg})$ of crude enzyme in this study is almost the same as that $(0.90 \mathrm{U} / \mathrm{mg})$ in the previous study [5]. So, it is thought that the difference of total activity might come from the variation of specimen, and the defatting condition with $\mathrm{SCO}_{2}$ in this study would not cause significant denaturation of fish trypsin.

3.2. Purification of SC-T. The SC-T was purified from the crude enzyme solution by two steps of chromatographies including Sephacryl S-200 and Sephadex G-50, which is the same purification procedure as that in the previous study [5]. The SC-T was consequently purified 48 -fold with a high recovery $(50 \%)$ from the crude enzyme solution (Table 1) and had a specific activity of $36 \mathrm{U} / \mathrm{mg}$ which is fairly higher than that of spotted mackerel trypsin [5]. In addition, the SC-T was found nearly homogeneous on SDS-PAGE (Figure 1), and its molecular weight was estimated as approximately 24,000 , which is similar to that of spotted mackerel trypsin [5]. Furthermore, the $\mathrm{N}$-terminal twenty amino acids sequence of SC-T was analyzed to be IVGGYECTPYSQPWTVSLNS that accords with that of spotted mackerel trypsin [5]. These results also show that the $\mathrm{SCO}_{2}$ defatting process in this study removes lipids in

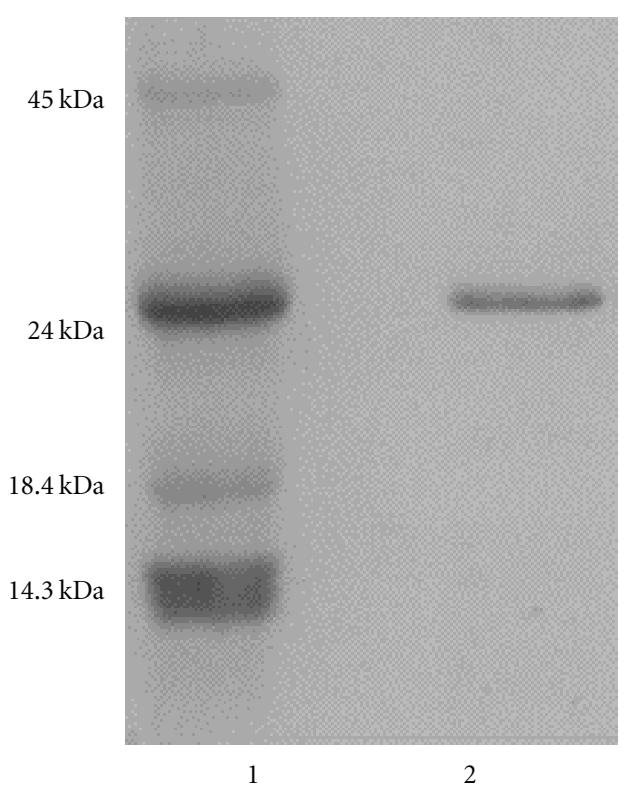

FIGURE 1: Electrophoresis of the trypsin (SC-T) purified from the mackerel (Scomber sp.) viscera defatted by $\mathrm{SCO}_{2}$. Electrophoresis was performed using a $0.1 \%$ SDS- $13.75 \%$ polyacrylamide slab gel. (1) contains protein standards; ovalbumin (molecular weight, $45 \mathrm{kDa})$, bovine pancreatic trypsinogen $(24 \mathrm{kDa})$, bovine milk blactoglobulin $(18.4 \mathrm{kDa})$, and egg-white lysozyme (14.3 kDa). (2) contains mackerel trypsin (SC-T).

fish viscera as effectively as acetone defatting process for preparation of fish trypsin.

Crude enzyme extract usually contains various proteins, and sometimes fish trypsin is composed of some isozymes. In general, the purification of fish trypsin was carried out by the combination of some types of chromatography [28-30]. However, we achieved a high purification of a trypsin from the mackerel viscera powder defatted by acetone using only two steps of gel filtration [5]. So, in this study, we purified the SC-T by gel filtration according to the previous study.

3.3. Enzymatic Properties of SC-T. The SC-T was strongly inhibited by specific trypsin inhibitors (soybean trypsin inhibitor and TLCK), but E-64 (cysteine proteinase inhibitor), pepstatin A (aspartic proteinase inhibitor), and EDTA (metalloproteinase inhibitor) had no inhibitory effect on the activity of SC-T (Table 2).

The influence of $\mathrm{pH}$ on the SC-T activity is shown in Figure 2(a). The enzyme hydrolyzed TAME substrate effectively between $\mathrm{pH} 7.0$ and 9.0, with an optimum around $\mathrm{pH}$ 8.0. The optimum $\mathrm{pH}$ of SC-T was the same as those of other fish trypsins [3-11, 31-38], but lower than those of bluefish ( $\mathrm{pH}$ 9.5) [39] and Atlantic bonito ( $\mathrm{pH}$ 9.0) [40]. Figure 2(b) shows the temperature dependencies of SC-T. The SC-T was active over a broad temperature range (20$70^{\circ} \mathrm{C}$ ) with the optimum at about $60^{\circ} \mathrm{C}$. Because mackerel is a temperate-zone fish, the SC-T possesses similar optimum temperature with other trypsins from temperate-zone fish, such as anchovy [3], true sardine [4], yellow tail [6], and 


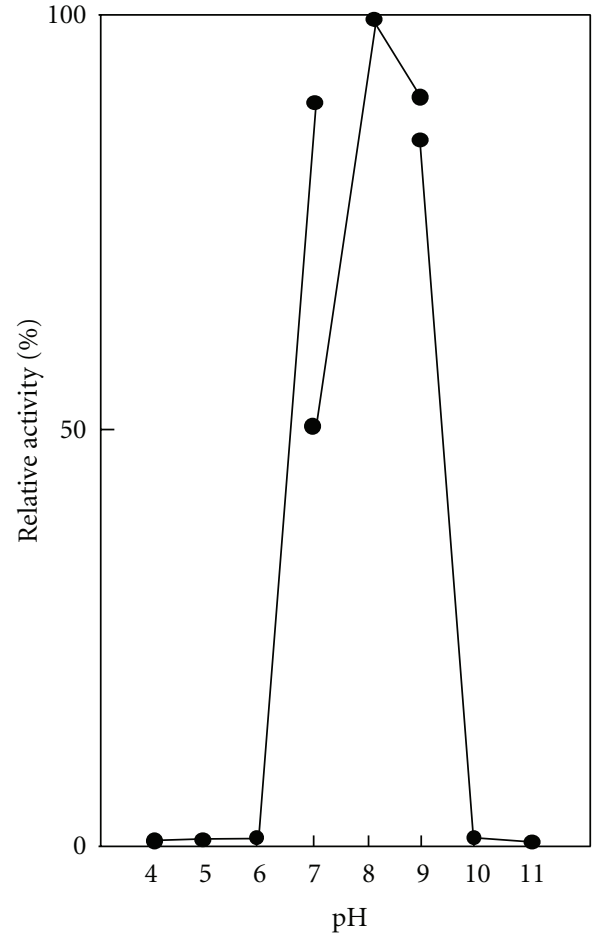

(a)

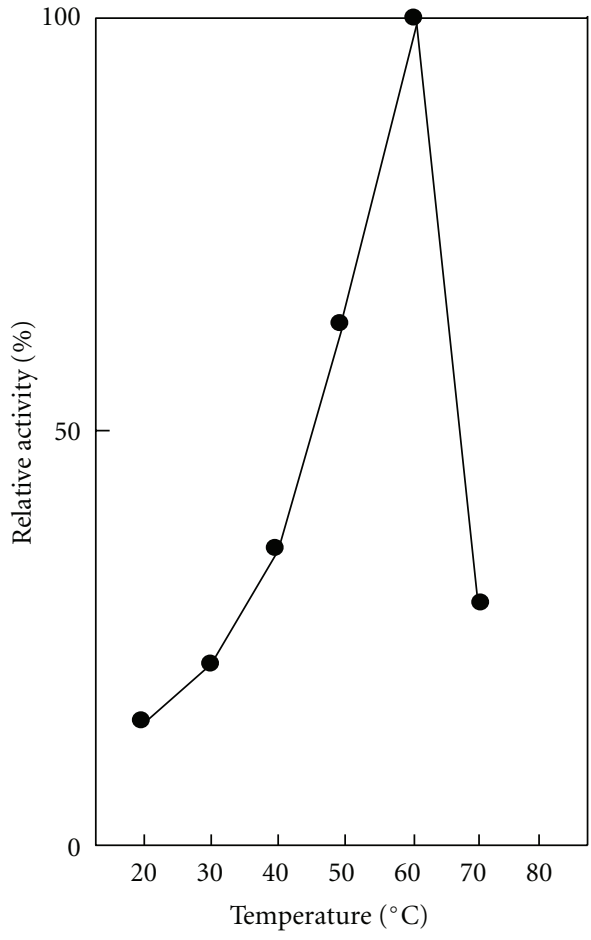

(b)

Figure 2: Effects of $\mathrm{pH}$ and temperature on the activity of SC-T. (a) The activity was determined in $50 \mathrm{mM}$ buffer solutions [acetic acidsodium acetate ( $\mathrm{pH} 4.0-7.0)$, Tris- $\mathrm{HCl}(\mathrm{pH} 7.0-9.0)$, and glycine- $\mathrm{NaOH}(\mathrm{pH} 9.0-11.0)$ ] at $37^{\circ} \mathrm{C}$. (b) The activity was determined at $\mathrm{pH} 8.0$ and at various temperatures.

jacopever [7]. The optimum temperature SC-T is slightly lower than those of tropical-zone fish (around $65^{\circ} \mathrm{C}$ ) [33$35,39,40]$ but is evidently higher than those of frigid-zone fish trypsins (around $50^{\circ} \mathrm{C}$ ) $[4,6-10]$.

The pH stability of SC-T is shown in Figure 3(a). The SC-T was stable at $30^{\circ} \mathrm{C}$ for $30 \mathrm{~min}$ in the $\mathrm{pH}$ range from $\mathrm{pH} 6.0$ to 11.0. Unlike mammalian trypsins, diminished stability of the trypsin was more pronounced after exposure at acidic $\mathrm{pH}$. Instability at acidic $\mathrm{pH}$ was also observed for other fish trypsins [1, 3-11, 32-35, 37, 39, 40]. For temperature stability, the SC-T was stable below $40^{\circ} \mathrm{C}$, but the activity quickly fell over $50^{\circ} \mathrm{C}$ (Figure 3(b)). While the $\mathrm{SC}-\mathrm{T}$ and other temperate-zone fish trypsins are relatively less stable than tropical-zone fish trypsins, they are obviously stable than frigid-zone fish trypsins $[8,10]$. As described previously, there is a strong relationship between habitat temperature of marine fish and thermostability of their trypsins $[8,10]$.

The effect of calcium ion on the stability of SC-T was then investigated. The stability of SC-T was enhanced by calcium ion (Figure 4). Similar results have been reported for various fish trypsins [1, 3-11, 33-35, 39, 40]. Bovine trypsinogen has two calcium-binding sites, and the primary site, with a higher affinity for calcium ions, is common in trypsinogen and trypsin and the secondary site is only in the zymogen $[41,42]$. Occupancy of the primary calcium-binding site stabilizes bovine trypsin toward thermal denaturation or autolysis $[41,42]$. In the previous paper, we described trypsin of arabesque greenling which also has the primary calciumbinding site [43]. The SC-T was stabilized by calcium ion from denaturation in this study. So, the result suggests that the SC-T may possess the primary calcium-binding site like bovine and arabesque greenling trypsins.

\section{Conclusion}

With the aim of utilization of fish trypsin for food industry, we purified a trypsin (SC-T) from mackerel (Scomber sp.) viscera powder treated by the $\mathrm{SCO}_{2}$ defatting process and compared its enzymatic properties with those of other fish trypsins purified from the viscera defatted by acetone. In this study, we adopted the condition of $40^{\circ} \mathrm{C}, 25 \mathrm{MPa}$, and $2.5 \mathrm{~h}$ to separate lipids from the viscera. Consequently, we could remove most of the lipids from the viscera and could extract considerable amount of trypsin from the defatted powder. The characteristics of purified SC-T were nearly the same as those of other fish trypsins, especially spotted mackerel trypsin. Therefore, we concluded that the $\mathrm{SCO}_{2}$ defatting process is useful as a substitute for the organic solvent defatting process.

\section{Acknowledgments}

The authors wish to thank Mr. Hirose, the Center for Instrumental Analysis, Hokkaido University, for amino acid sequence analysis. This research was supported in part by 


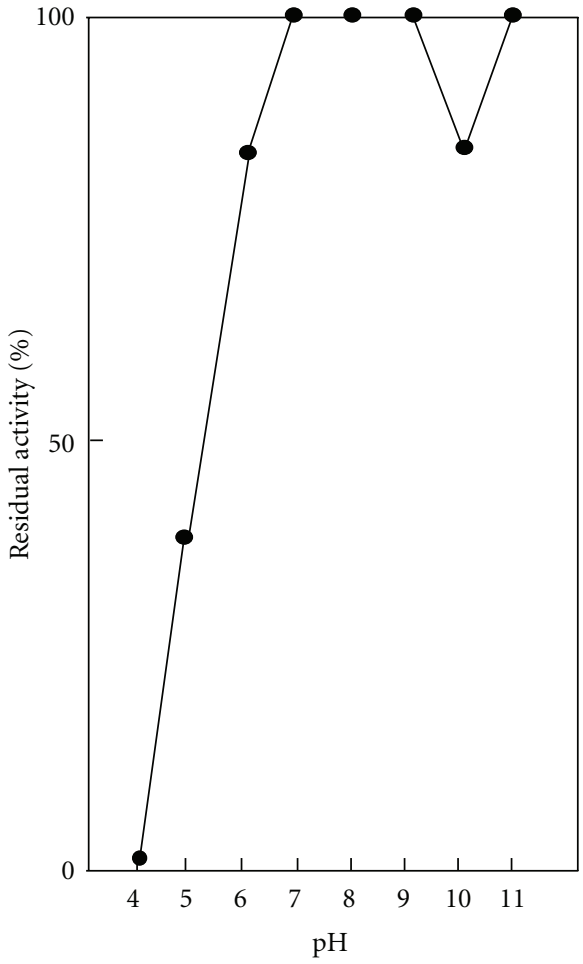

(a)

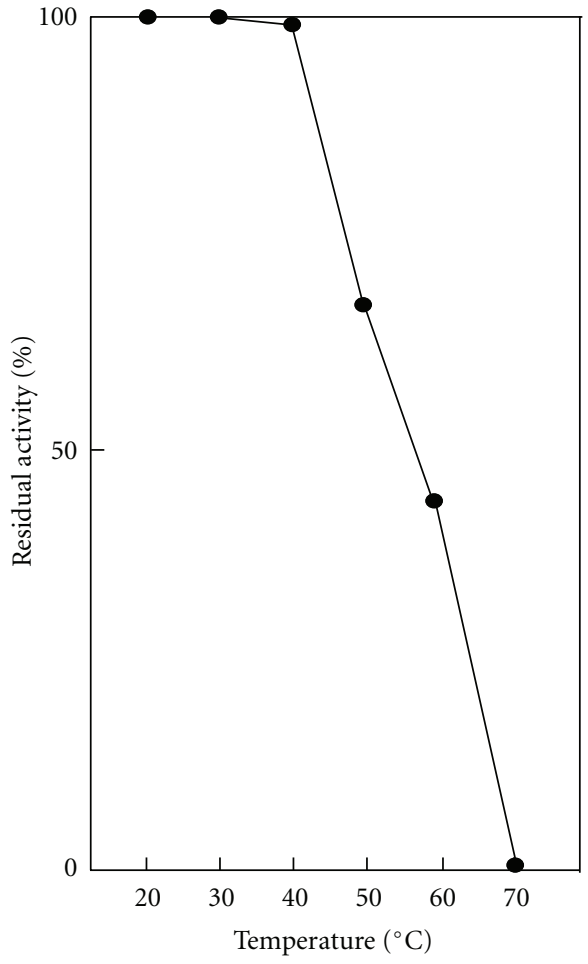

(b)

Figure 3: $\mathrm{pH}$ and temperature stability of SC-T. (a) The enzyme was kept at $30^{\circ} \mathrm{C}$ for $30 \mathrm{~min}$ and $\mathrm{pH} 4.0-11.0$, and then the remaining activity at $30^{\circ} \mathrm{C}$ and $\mathrm{pH} 8.0$ was determined. (b) The enzyme was kept at $20-70^{\circ} \mathrm{C}$ for $15 \mathrm{~min}$ and $\mathrm{pH} 8.0$, and then the remaining activity at $30^{\circ} \mathrm{C}$ and $\mathrm{pH} 8.0$ was determined.

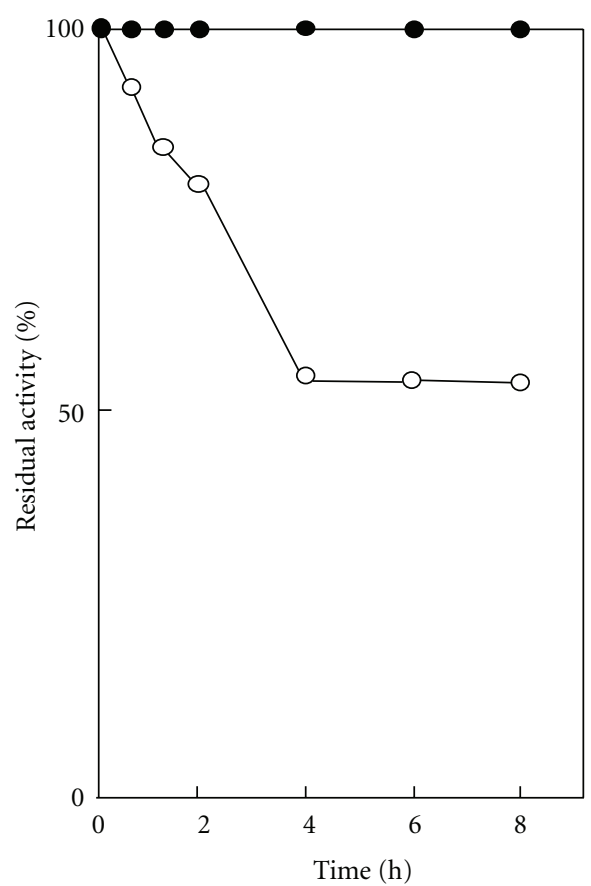

FIGURE 4: Effect of calcium ion on the stability of SC-T. The enzyme was kept at $30^{\circ} \mathrm{C}$ and $\mathrm{pH} 8.0$ for $0-8 \mathrm{~h}$ in the presence of $10 \mathrm{mM}$ $\mathrm{CaCl}_{2}$ (closed symbol) or $10 \mathrm{mM}$ EDTA (open symbol), and then the remaining activity at $30^{\circ} \mathrm{C}$ and $\mathrm{pH} 8.0$ was determined. a grant of HOKUSUI Association and was also supported by a grant from Marine Bioprocess Research Center of the Marine Biotechnology Program funded by the Ministry of Land, Transport and Maritime, Republic of Korea. They also appreciate the support of the Core University Program on Fisheries Sciences founded by JSPS \& KOSEF.

\section{References}

[1] M. M. Kristjansson, "Purification and characterization of trypsin from the fyioric caeca of rainbow trout (Oncorhynchus mykiss)," Journal of Agricultural and Food Chemistry, vol. 39, no. 10, pp. 1738-1742, 1991.

[2] B. Stefansson, L. Helgadottir, S. Olafsdottir, A. Gudmundsdottir, and J. B. Bjarnason, "Characterization of cold-adapted Atlantic cod (Gadus morhua) trypsin I-Kinetic parameters, autolysis and thermal stability," Comparative Biochemistry and Physiology. Part B, vol. 155, no. 2, pp. 186-194, 2010.

[3] H. Kishimura, K. Hayashi, Y. Miyashita, and Y. Nonami, "Characteristics of two trypsin isozymes from the viscera of Japanese anchovy (Engraulis japonica)," Journal of Food Biochemistry, vol. 29, no. 5, pp. 459-469, 2005.

[4] H. Kishimura, K. Hayashi, Y. Miyashita, and Y. Nonami, "Characteristics of trypsins from the viscera of true sardine (Sardinops melanostictus) and the pyloric ceca of arabesque greenling (Pleuroprammus azonus)," Food Chemistry, vol. 97, no. 1, pp. 65-70, 2006. 
[5] H. Kishimura, Y. Tokuda, S. Klomklao, S. Benjakul, and S. Ando, "Enzymatic characteristics of trypsin from pyloric CECA of spotted mackerel (Scomber australasicus)," Journal of Food Biochemistry, vol. 30, no. 4, pp. 466-477, 2006.

[6] H. Kishimura, Y. Tokuda, S. Klomklao, S. Benjakul, and S. Ando, "Comparative study of enzymatic characteristics of trypsins from the pyloric ceca of yellow tail (Seriola quinqueradiata) and brown hakeling (Physiculus japonicus)," Journal of Food Biochemistry, vol. 30, no. 5, pp. 521-534, 2006.

[7] H. Kishimura, Y. Tokuda, M. Yabe, S. Klomklao, S. Benjakul, and S. Ando, "Trypsins from the pyloric ceca of jacopever (Sebastes schlegelii) and elkhorn sculpin (Alcichthys alcicornis): isolation and characterization," Food Chemistry, vol. 100, no. 4, pp. 1490-1495, 2007.

[8] H. Kishimura, S. Klomklao, S. Benjakul, and B. S. Chun, "Characteristics of trypsin from the pyloric ceca of walleye pollock (Theragra chalcogramma)," Food Chemistry, vol. 106, no. 1, pp. 194-199, 2008.

[9] T. Fuchise, H. Kishimura, H. Sekizaki et al., "Purification and characteristics of trypsins from cold-zone fish, Pacific cod (Gadus macrocephalus) and saffron cod (Eleginus gracilis)," Food Chemistry, vol. 116, no. 3, pp. 611-616, 2009.

[10] H. Kishimura, S. Klomklao, S. Nalinanon, S. Benjakul, B. S. Chun, and K. Adachi, "Comparative study on thermal stability of trypsin from the pyloric ceca of threadfin hakeling (Laemonema longipes)," Journal of Food Biochemistry, vol. 34, no. 1, pp. 50-65, 2010.

[11] G. Kanno, T. Yamaguchi, H. Kishimura, E. Yamaha, and H. Saeki, "Purification and characteristics of trypsin from masu salmon (Oncorhynchus masou) cultured in fresh-water," Fish Physiology and Biochemistry, vol. 36, no. 3, pp. 637-645, 2010.

[12] B. K. Simpson and N. F. Haard, "Marine enzymes," in Encyclopedia of Food Science and Technology, F. J. Francis, Ed., vol. 3, pp. 1525-1534, John Wiley \& Sons, New York, NY, USA, 2nd edition, 1999.

[13] A. Gudmundsdottir and H. M. Palsdottir, "Atlantic cod trypsins: from basic research to practical applications," Marine Biotechnology, vol. 7, no. 2, pp. 77-88, 2005.

[14] A. B. J. Gudmundsdottir, "Applications of cold adapted proteases in the food industry," in Nobel Enzyme Technology for Food Applications, B. Rastall, Ed., chapter 10, pp. 205-214, Woodhead Publishing Limited, Cambridge, UK, 2007.

[15] T. Fuchise, H. Kishimura, Z. H. Yang, M. Kojoma, E. Toyota, and H. Sekizaki, "Atlantic cod trypsin-catalyzed peptide synthesis with inverse substrates as acyl donor components," Chemical and Pharmaceutical Bulletin, vol. 58, no. 4, pp. 484487, 2010.

[16] H. Kishimura and K. Hayashi, "Isolation and characteristics of phospholipase A2 from the pyloric ceca of the starfish Asterina pectinifera," Comparative Biochemistry and Physiology. Part B, vol. 124 , no. 4, pp. 483-488, 1999.

[17] H. Kishimura and K. Hayashi, "Isolation and characteristics of trypsin from pyloric ceca of the starfish Asterina pectinifera," Comparative Biochemistry and Physiology. Part B, vol. 132, no. 2, pp. 485-490, 2002.

[18] M. S. Uddin, H. M. Ahn, H. Kishimura, and B. S. Chun, "Comparative study of digestive enzymes of squid (Todarodes pacificus) viscera after supercritical carbon dioxide and organic solvent extraction," Biotechnology and Bioprocess Engineering, vol. 14, no. 3, pp. 338-344, 2009.

[19] K. Y. Kang, D. H. Ahn, G. T. Wilkinson, and B. S. Chun, "Extraction of lipids and cholesterol from squid oil with supercritical carbon dioxide," Korean Journal of Chemical Engineering, vol. 22, no. 3, pp. 399-405, 2005.
[20] K. Yamaguchi, M. Murakami, H. Nakano et al., "Supercritical carbon dioxide extraction of oils from Antarctic krill," Journal of Agricultural and Food Chemistry, vol. 34, no. 5, pp. 904-907, 1986.

[21] F. Temelli, E. Leblanc, and L. Fu, "Supercritical carbon dioxide extraction of oil from Atlantic mackerel (Scomber scombrus) and protein functionality," Journal of Food Science, vol. 60, no. 4, pp. 703-706, 1995.

[22] J. Y. Park, M. K. Lee, M. S. Uddin, and B. S. Chun, "Removal of off-flavors and isolation of fatty acids from boiled anchovies using supercritical carbon dioxide," Biotechnology and Bioprocess Engineering, vol. 13, no. 3, pp. 298-303, 2008.

[23] B. S. Chun, H. Kishimura, H. Kanzawa et al., "Application of supercritical carbon dioxide for preparation of starfish phospholipase A2," Process Biochemistry, vol. 45, no. 5, pp. 689-693, 2010.

[24] B. C. W. Hummel, "A modified spectrophotometric determination of chymotrypsin, trypsin, and thrombin," Canadian Journal of Biochemistry and Physiology, vol. 37, no. 12, pp. 1393-1399, 1959.

[25] S. Klomklao, S. Benjakul, and W. Visessanguan, "Comparative studies on proteolytic activity of splenic extract from three tuna species commonly used in Thailand," Journal of Food Biochemistry, vol. 28, no. 5, pp. 355-372, 2004.

[26] U. K. Laemmli, "Cleavage of structural proteins during the assembly of the head of bacteriophage T4," Nature, vol. 227, no. 5259, pp. 680-685, 1970.

[27] O. H. Lowry, N. J. Rosebrough, A. L. Farr, and R. J. Randall, "Protein measurement with the Folin phenol reagent," The Journal of biological chemistry, vol. 193, no. 1, pp. 265-275, 1951.

[28] H. B. Khaled, A. Bougatef, R. Balti, Y. Triki-Ellouz, N. Souissi, and M. Nasri, "Isolation and characterisation of trypsin from sardinelle (Sardinella aurita) viscera," Journal of the Science of Food and Agriculture, vol. 88, no. 15, pp. 2654-2662, 2008.

[29] K. Jellouli, A. Bougatef, D. Daassi, R. Balti, A. Barkia, and M. Nasri, "New alkaline trypsin from the intestine of grey triggerfish (Balistes capriscus) with high activity at low temperature: purification and characterisation," Food Chemistry, vol. 116, no. 3, pp. 644-650, 2009.

[30] A. Bougatef, R. Balti, R. Nasri, K. Jellouli, N. Souissi, and M. Nasri, "Biochemical properties of anionic trypsin acting at high concentration of $\mathrm{NaCl}$ purified from the intestine of a carnivorous fish: smooth hound (Mustelus mustelus)," Journal of Agricultural and Food Chemistry, vol. 58, no. 9, pp. 57635769, 2010.

[31] B. K. Simpson and N. F. Haard, "Trypsin from greenland cod, Gadus ogac. Isolation and comparative properties," Comparative Biochemistry and Physiology. Part B, vol. 79, no. 4, pp. 613-622, 1984.

[32] B. Asgeirsson, J. W. Fox, and J. B. Bjarnason, "Purification and characterization of trypsin from the poikilotherm Gadus morhua," European Journal of Biochemistry, vol. 180, no. 1, pp. 85-94, 1989.

[33] S. Klomklao, S. Benjakul, W. Visessanguan, H. Kishimura, B. K. Simpson, and H. Saeki, "Trypsins from yellowfin tuna (Thunnus albacores) spleen: purification and characterization," Comparative Biochemistry and Physiology. Part B, vol. 144, no. 1, pp. 47-56, 2006.

[34] S. Klomklao, S. Benjakul, W. Visessanguan, H. Kishimura, and B. K. Simpson, "Purification and characterization of trypsin from the spleen of tongol tuna (Thunnus tonggol)," Journal of Agricultural and Food Chemistry, vol. 54, no. 15, pp. 56175622, 2006. 
[35] S. Klomklao, S. Benjakul, W. Visessanguan, H. Kishimura, and B. K. Simpson, "Purification and characterisation of trypsins from the spleen of skipjack tuna (Katsuwonus pelamis)," Food Chemistry, vol. 100, no. 4, pp. 1580-1589, 2007.

[36] K. Hjelmeland and J. Raa, "Characteristics of two trypsin type isozymes isolated from the Arctic fish capelin (Mallotus villosus)," Comparative Biochemistry and Physiology. Part B, vol. 71, no. 4, pp. 557-562, 1982.

[37] A. Martínez, R. L. Olsen, and J. L. Serra, "Purification and characterization of two trypsin-like enzymes from the digestive tract of anchovy Engraulis encrasicholus," Comparative Biochemistry and Physiology. Part B, vol. 91, no. 4, pp. 677684, 1988.

[38] F. J. Castillo-Yáñez, R. Pacheco-Aguilar, F. L. Garcia-Carreno, and M. D. L. A. Navarrete-Del Toro, "Isolation and characterization of trypsin from pyloric caeca of Monterey sardine Sardinops sagax caerulea," Comparative Biochemistry and Physiology. Part B, vol. 140, no. 1, pp. 91-98, 2005.

[39] S. Klomklao, S. Benjakul, W. Visessanguan, H. Kishimura, and B. K. Simpson, "Trypsin from the pyloric caeca of bluefish (Pomatomus saltatrix)," Comparative Biochemistry and Physiology. Part B, vol. 148, no. 4, pp. 382-389, 2007.

[40] S. Klomklao, S. Benjakul, W. Visessanguan, H. Kishimura, and B. K. Simpson, "A $29 \mathrm{kDa}$ protease from the digestive glands of Atlantic bonito (Sarda sarda): recovery and characterization," Journal of Agricultural and Food Chemistry, vol. 55, no. 11, pp. 4548-4553, 2007.

[41] A. A. Kossiakoff, J. L. Chambers, L. M. Kay, and R. M. Stroud, "Structure of bovine trypsinogen at $1.9 \AA$ resolution," Biochemistry, vol. 16, no. 4, pp. 654-664, 1977.

[42] K. A. Walsh, "Trypsinogens and trypsins of various species," Methods in Enzymology, vol. 19, pp. 41-63, 1970.

[43] G. Kanno, H. Kishimura, S. Ando et al., "Structural properties of trypsin from cold-adapted fish, arabesque greenling (Pleurogrammus azonus)," European Food Research and Technology, vol. 232, no. 3, pp. 381-388, 2011. 

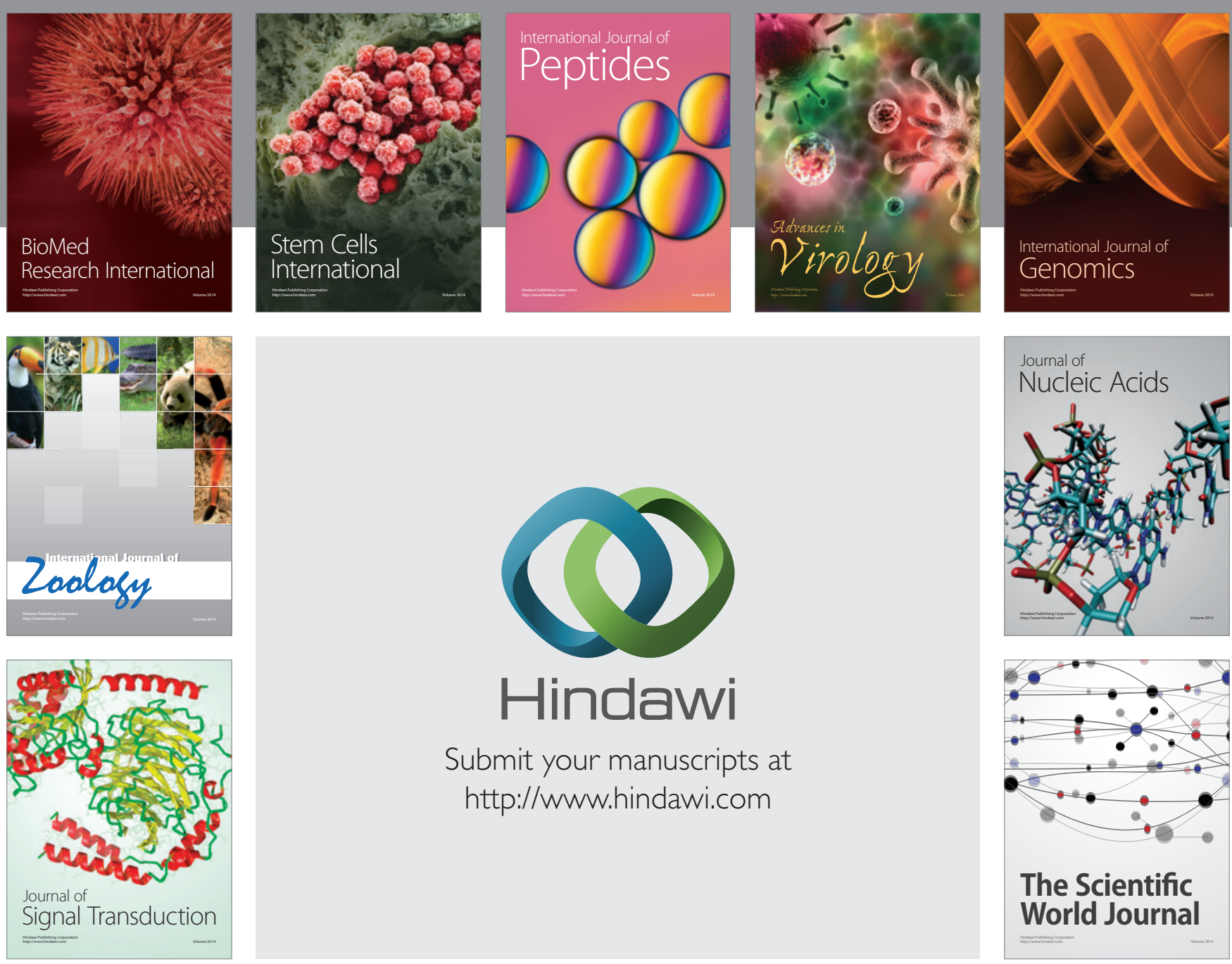

Submit your manuscripts at

http://www.hindawi.com
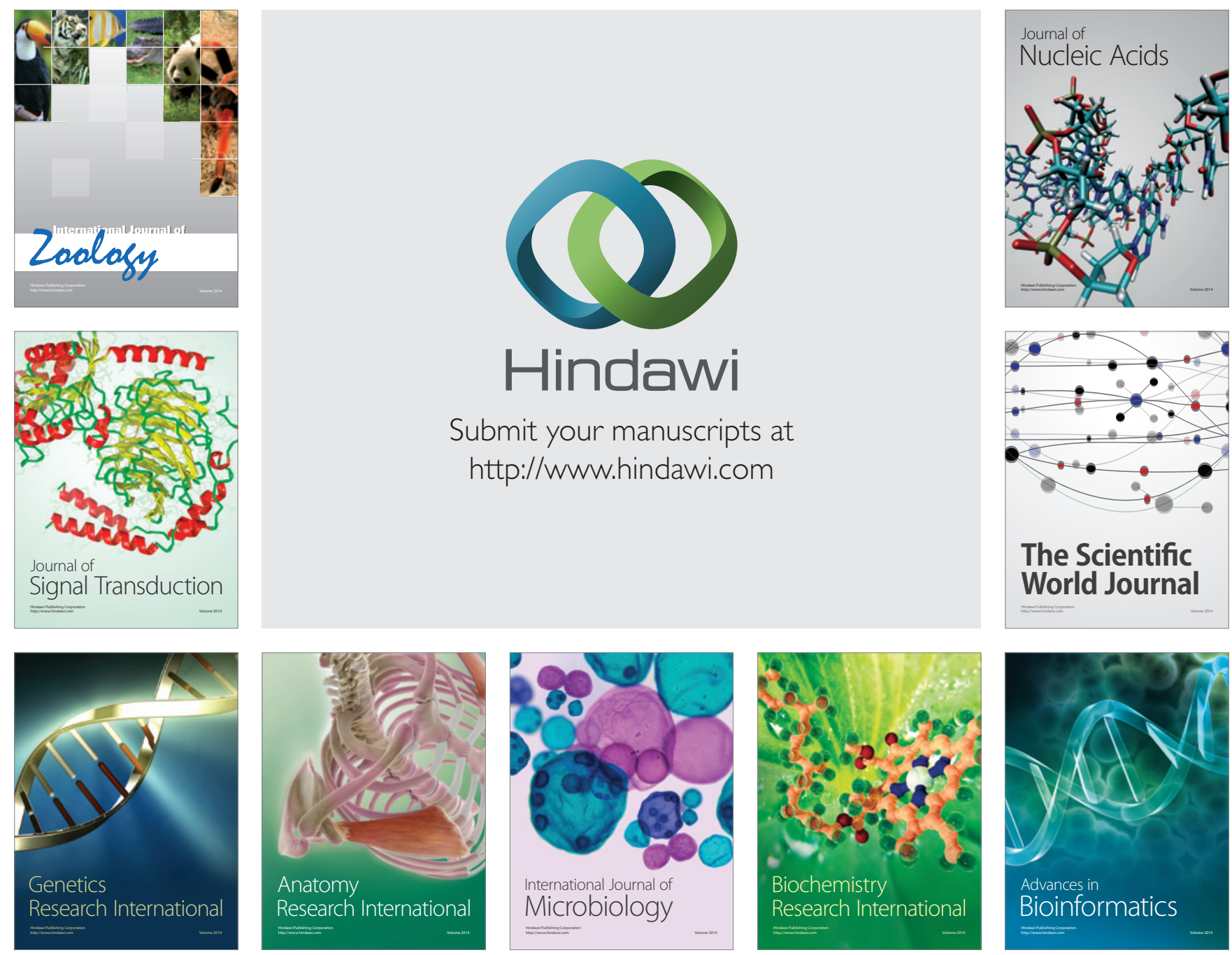

The Scientific World Journal
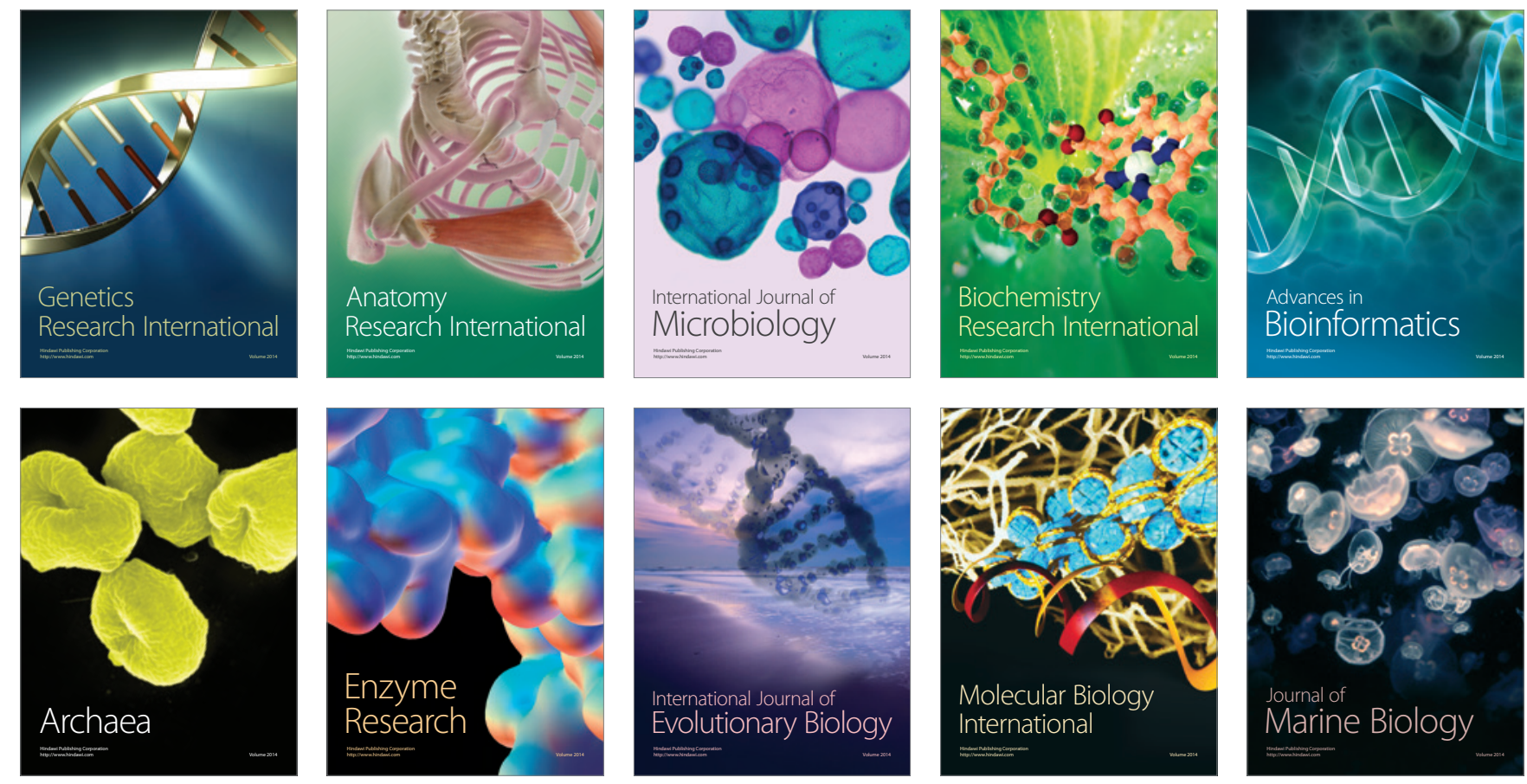